\title{
Anemia in children with chronic renal failure Special attention erythrocyte indices and iron deficiency anemia
}

\author{
Adi Suryanto B, Partini P Trihono, Agus Firmansyah
}

\begin{abstract}
Background Anemia in chronic renal failure (CRF) has been proved to influence the quality of life, increasing morbidity and mortality. Early diagnosis and prompt treatments of anemia are mandatory to manage CRF appopriately. So far data of anemia in CRF in Indonesia is limited.

Objective To find out the profile of anemia in children with CRF at Cipto Mangunkusumo Hospital (CMH), Jakarta, with special attention in erythrocyte indices and iron deficiency anemia.

Methods Cross-sectional descriptive study was carried out on patients with CRF and anemia in $\mathrm{CMH}$ since October 2003 to April 2004.

Results There were 20 CRF patients, aged between 1 year 3 month15 year old, mostly were above 10 year old, 11 patients were males and 9 were females. The most frequent etiologies were urinary tract infection (UTI) in 10 cases and nephrotic syndrome in 6 cases. Of those 20 patients, 14 suffered from anemia with erythrocyte indices, normochrome normocytic in 9 patients and hypochrome microcytic in 5 patients. Of 14 anemic patients only 1 patient suffered from iron deficiency anemia of less than $10 \mathrm{mg} / \mathrm{l}$ and transferin saturation of less than $12 \%$. Based on serum iron (SI) concentration only, 7 patients were diagnosed as having iron deficiency anemia.

Conclusion Most patients with chronic renal failure have normochrome normocytic anemia. Hypochromic microcytic iron deficiency anemia is scarcely found in this group of patients. [Paediatr Indones 2006;46:154-158].
\end{abstract}

Keywords: chronic renal failure, anemia, iron deficiency

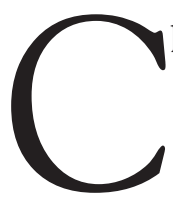

hronic renal failure (CRF) is defined as an irreversible loss of renal function as a result of decrease glomerular filtration rate (GFR). ${ }^{1}$ The incidence of CRF in children tends to increase. In Cipto Mangunkusumo Hospital $(\mathrm{CMH})$, Jakarta, the incidence of CRF in children between 1991 to 1995 was $4.9 \%$ out of 688 children with kidney diseases. This incidence increased to 13.3\% out of 435 children between 1996 to 2000.2,3 Anemia is one of the symptoms which is common in CRF patients. ${ }^{4}$ Anemia in CRF has been associated with the quality of life, morbidity, and mortality; therefore it should be managed optimally.5,6 Annual report by North American Pediatric Transplant Cooperative Study (NAPRTCS) in 1996 clarified that $25.7 \%$ patients who had GFR between $25-50 \mathrm{ml} /$ minutes $/ 1.73 \mathrm{~m}^{2}$ and $13.1 \%$ patients who had GFR between $50-75 \mathrm{ml} /$ minutes $/ 1.73 \mathrm{~m}^{2}$ suffered from anemia. ${ }^{7}$ The cause of anemia in CRF is multifactorial,

From the Department of Child Health, Medical School, University of Indonesia, Jakarta, Indonesia.

Reprint requests to: Adi Suryanto B, MD, Department of Child Health, Medical School, University of Indonesia, Cipto Mangunkusumo Hospital, Jl. Salemba 6, Jakarta, Indonesia. Tel. 62-21-3161144. Fax. 62-21-3907743. Email: adisuryanto@hotmail.com. 
even that the primary cause is erythropoetin deficiency. Iron deficiency is one of the etiology of anemia in CRF.8-10

Early diagnosis to detect the cause of anemia and prompt treatment can improve CRF management totally. The determination of anemia is done through anamnesis, physical examination, and simple laboratory examinations such as hemoglobin $(\mathrm{Hb})$, hematocrit $(\mathrm{Ht})$, erythrocyte, reticulocyte count, erythrocyte indices, and specific laboratory examinations according to indications. ${ }^{11}$ Studies done by Maiz et al ${ }^{12}$ obtained the incidence of iron deficiency anemia in CRF patients was $21.6 \%$. The aim of this study was to find out the profile of anemia in children with CRF at $\mathrm{CMH}$, with special attention in the erythrocyte indices and iron deficiency anemia.

\section{Methods}

This was a cross-sectional study on patients with CRF treated at the Department of Child Health, Cipto Mangunkusumo Hospital, in October 2003-April 2004. The diagnosis of CRF was established by pediatric nephrologists in our hospital. The diagnosis of CRF was confirmed if GFR was less than $80 \mathrm{ml} /$ minute $/ 1.73 \mathrm{~m}^{2}$ in at least 3 consecutive months. GFR was measured by Schwartz formula. ${ }^{13}$ Anemia was confirmed if $\mathrm{Hb}$ was less than $11 \mathrm{~g} / \mathrm{dl}$ for children younger than 6 years or $\mathrm{Hb}$ less than $12 \mathrm{~g} / \mathrm{dl}$ for children older than 6 years. ${ }^{14}$ Criteria of iron deficiency anemia in this study was serum ferritin concentration less than $10 \mu \mathrm{g} / \mathrm{l}$ and transferrin saturation less than $12 \% .{ }^{15}$ Classification of anemia into hypochrome microcytic or normochrome normocytic was based on $\mathrm{MCV}, \mathrm{MCH}$, and $\mathrm{MCHC}$ findings. Nutritional status was determined based on Lokakarya Antropometri Gizi Depkes 1974 and Puslitbang Gizi 1978. ${ }^{16}$

\section{Results}

From October 2003 until April 2004, there were 20 CRF patients, with the age ranged between 1 year to 15 years, consisted of 11 males and 9 females. Of those 20 patients, 14 suffered from anemia, one of them suffered from iron deficiency anemia.
Table 1 shows that most of CRF patients were above 10 years old (11 patients). There was no patient with severe malnutrition. Twelve of 20 patients showed erythrocyte indices of normochrome normocytic, while the other 8 patients showed hypochrome microcytic. Urinary tract infection (UTI) was the most frequent (10 patients) underlying disease of CRF, followed by nephrotic syndrome (6 patients). There were 12 CRF patients who had GFR less than $25 \mathrm{ml} /$ minute $/ 1.73 \mathrm{~m}^{2}$.

TABle 1. Subject Characteristics

\begin{tabular}{lc}
\hline Subjects' characteristics & Total $(\mathbf{n}=\mathbf{2 0})$ \\
\hline Age (years) & \\
$<5$ & 3 \\
$5-10$ & 6 \\
$>10$ & 11 \\
Sex & \\
$\quad$ Male & 11 \\
Female & 9 \\
Nutritional status & \\
Well nourished & 7 \\
Mild undernourished & 13 \\
Erythrocyte indices & \\
Normochrome normocytic & 12 \\
Hypochrome microcytic & 8 \\
GFR (ml/mnt/1.73m ${ }^{2}$ ) & \\
$\quad<25$ & 12 \\
$25-50$ & 3 \\
$>50-<80$ & 5 \\
Etiology & \\
UTI & 10 \\
Nephrotic syndrome (NS) & 6 \\
Rapidly Progressive Glomerulo-Nephritis (RPGN) & 2 \\
Neurogenic bladder & 1 \\
Single contracted kidney & 1 \\
\hline &
\end{tabular}

Table 2 shows the distribution of anemia according to clinical and laboratory findings. Most of the patients aged more than 10 years ( 9 patients). There were 14 anemic patients with CRF, 8 were males and 6 were females. Nine patients were mild undernourished and 5 patients were well nourished. Erythrocyte indices of normochrome normocytic were found in 9 patients and hypochrome microcytic in 5 patients. Most of the anemic patients had GFR less than $25 \mathrm{ml} / \mathrm{minute} / 1.73 \mathrm{~m}^{2}$. Of those 14 anemic patients, 9 patients had a normal number of reticulocyte count and 5 patients had increase reticulocyte count.

Of those 14 anemic patients, only 2 showed low serum ferritin and 3 patients with low transferrin satu- 
Table 2. Distribution of anemia according to age, SEX, NUTRITIONAL STATUS, IRON INDICES, RETICULOCYTE COUNT, AND GFR

\begin{tabular}{lccc}
\hline \multirow{2}{*}{ Subjects' characteristics } & \multicolumn{2}{c}{ Anemia } & \multirow{2}{*}{ Total } \\
& Yes & No & \\
\hline Age(years) & & & \\
$\quad<5$ & 2 & 1 & 3 \\
$5-10$ & 3 & 3 & 6 \\
$\quad>10$ & 9 & 2 & 11 \\
$\quad \begin{array}{l}\text { Sex } \\
\quad \text { Male }\end{array}$ & 8 & 3 & 11 \\
$\quad$ Female & 6 & 3 & 9 \\
$\quad$ Nutritional status & & & \\
$\quad$ Well nourished & 5 & 2 & 7 \\
$\quad$ Mild undernourished & 9 & 4 & 13 \\
Erythrocyte indices & & & \\
$\quad$ Normochrome normocytic & 9 & 3 & 12 \\
$\quad$ Hypochrome microcytic & 5 & 3 & 8 \\
Reticulocyte count & & & \\
$\quad$ Normal & 9 & 3 & 12 \\
$\quad$ Increased & 5 & 3 & 8 \\
GFR(ml/min/1.73m ${ }^{2}$ ) & & & \\
$\quad<25$ & 10 & 2 & 12 \\
$\quad 25-50$ & 2 & 1 & 3 \\
$\quad>50-80$ & 2 & 3 & 5 \\
\hline
\end{tabular}

ration. There was only 1 patient who had iron deficiency anemia, i.e. 12 year old female patient who was mildly undernourished. Table 3 shows distribution of total subjects of this study according to criteria of iron deficiency anemia.

Table 3. Total SUbJects according to CRiteria of IRON DEFICIENCY ANEMIA

\begin{tabular}{lc}
\hline \multicolumn{1}{c}{ Criteria of iron deficiency anemia } & Total \\
\hline Hypochrome microcytic & 5 \\
Low SI & 7 \\
Low SI and high TIBC & 0 \\
Transferrin saturation $<20 \%$ & 5 \\
Serum ferritin $<10 \mu \mathrm{g} / \mathrm{l}$ and transferrin saturation $<12 \%$ & 1 \\
\hline
\end{tabular}

\section{Discussion}

During the period of study, 20 cases of CRF enrolled consisted of 11 males and 9 females. The result of this study is in accordance with that of the studies of Akinsola et $a^{17}$ in Nigeria, Maiz et al ${ }^{12}$ in Tunisia, and Madani et $a^{18}$ in Iran. Most of the patients in this study were above 10 years old, which is in accordance with that of the study of Logomarsimo ${ }^{19}$ in Chili.

Most CRF etiology in this study was UTI (10 patients), followed by NS (6 patients), RPGN (2 pa- tients), neurogenic bladder (1 patient), and single contracted kidney (1 patient). Two most common etiologies in this study were in accordance with the studies done by Trihono ${ }^{20}$ in the Department of Child Health, Cipto Mangunkusumo Hospital, between 1991-1995.

Fourteen out of $20 \mathrm{CRF}$ patients suffered from anemia. Study by Maiz et al ${ }^{12}$ obtained that anemia incidence in CRF is higher, i.e. 267 out of 304 patients. This difference was possibly due to the different criteria of anemia used. Maiz et al ${ }^{12}$ only used 1 criterion to determine anemia, i.e. Hb less than $12 \mathrm{~g} /$ $\mathrm{dl}$, while this study used 2 criteria (children $<6$ years old with $\mathrm{Hb}$ level $<11 \mathrm{~g} / \mathrm{dl}$ and children $>6$ years old with $\mathrm{Hb}<12 \mathrm{~g} / \mathrm{dl}$ ). If the criterion of Maiz et all ${ }^{12}$ was used in this study, the number of anemic patients increased to 16 out of 20 patients studied.

In $14 \mathrm{CRF}$ patients with anemia, the erythrocyte indices were normochrome normocytic in 9 patients and hypochrome microcytic in 5 patients. Studies by Talwar et $a^{21}$ in India found different results. There were 3 patients with erythrocyte indices of hypochrome microcytic with normal $\mathrm{Hb}$ level. Iron deficiency anemia can be categorized as advanced stadium of iron deficiency with hypochrome microcytic feature. Out of 14 anemic patients, 9 had a normal reticulocyte count, and in only 5 patients were the reticulocyte count increased. Wu et a ${ }^{22} \mathrm{ob}$ tained decreased reticulocyte count in most of their patients.

Distribution of anemia according to GFR showed that the lower the GFR, the higher the incidence of anemia. In this study there were 10 anemic patients with GFR of less than $25 \mathrm{ml} / \mathrm{mnt} / 1.73 \mathrm{~m}^{2}, 2$ with GFR between $25-50 \mathrm{ml} / \mathrm{mnt} / 1.73 \mathrm{~m}^{2}$, and 2 with GFR more than 50 until less than $80 \mathrm{ml} / \mathrm{mnt} / 1.73 \mathrm{~m}^{2}$. Annual report 1996 by NAPRTCS clarified that $25.7 \%$ patients who had GFR between $25-50 \mathrm{ml} / \mathrm{mnt} / 1.73 \mathrm{~m}^{2}$ and $13.1 \%$ patients who had GFR between $50-75 \mathrm{ml} /$ $\mathrm{mnt} / 1.73 \mathrm{~m}^{2}$ suffered from anemia. ${ }^{7}$

The easiest and the most common methods to evaluate iron store is serum ferritin. This study showed that out of 14 anemic children, only 2 had low serum ferritin, while the other had normal or even increased serum ferritin concentration. Talwar et $a^{21}$ in their studies found that $62 \%$ of the patients had low serum ferritin concentration. This difference may be caused by factors which can influence the result of serum fer- 
ritin examination such as inflammation or infection. Children with CRF are vulnerable to infection. In developing countries, the incidence of enteritis and parasite infestations are still quite high. This might also influence the result of serum ferritin examination in this study.

SI level can also be used as criteria of iron deficiency anemia. Based only on SI concentration, there were 7 patients with iron deficiency anemia (Table 3). Talwar et $a^{21}$ in their studies noted that $74 \%$ of patients had low serum iron concentration. This difference may due to some factors which can influence the result of serum iron examination such as iron absorption from food, infection, and inflammation. ${ }^{22}$ Transferrin saturation in this study tended to be normal or increasing. This is caused by the low number of iron binding capacity (IBC) that may be associated with low serum protein concentration. We did not measure protein concentration in the present study.

We only documented 1 patient who had deficiency anemia based on serum ferritin concentration of less than $10 \mu \mathrm{g} / \mathrm{l}$ and transferrin saturation less than $12 \% .{ }^{15}$ Maiz et $a^{12}$ found the incidence of iron deficiency anemia on CRF was as much as $21.6 \%$. This difference might be due to the different criteria of iron deficiency anemia used. Maiz et al ${ }^{12}$ only used transferrin saturation as a single criterion, as well as the level of transferrin saturation which was less than $20 \%$. If Maiz's criteria used in this study, there would be 5 patients diagnosed as iron deficiency anemia.

In conclusion, the prevalence of anemia in children with CRF treated in the Department of Child Health, CMH, since October 2003-April 2004 was 14 out of 20 patients. Erythrocyte indices in anemic patients with CRF showed normochrome normocytic in 9 patients and hypochrome microcytic in 5 patients. Iron deficiency anemia was found in 1 out of 14 anemic patients. When based on serum iron concentration only, the iron deficiency anemia was found in 7 out of 14 anemic patients.

\section{References}

1. Kher KK. Chronic renal failure. In: Kher KK, Makker SP, editors. Clinical pediatric nephrology. New York: Mc Graw-Hill, Inc.; 1992. p. 501-41.
2. Trihono PP. Terapi konservatif untuk mencegah penurunan fungsi ginjal yang progresif pada gagal ginjal. In: Naskah lengkap SINAS Nefrologi Anak VIII. Palembang: IDAI; 2001. p. 163-73.

3. Trihono PP. Penatalaksanaan gagal ginjal kronik pada anak. In: Naskah Lengkap SINAS Nefrologi Children VII. Ujung Pandang: IDAI; 1998. p. 133-50.

4. Nissenson AR. Introduction to anemia. Am J Kidney Dis 1998;32:131-2.

5. Foley RN, Parfrey PS, Harnett JD, Kent GM, Murray DC, Barre PE. The impact of anemia on cardiomyopathy, morbidity, and mortality in end-stage renal disease. Am J Kidney Dis 1996;28:53-61.

6. Perhimpunan Nefrologi Indonesia. Konsensus manajemen anemia pada patients gagal ginjal kronik. Pernefri; 2001.

7. Fivush BA, Jabs K, Neu AM, Sullivan EK, Feld L, Kohaut $\mathrm{E}$, et al. Chronic renal insufficiency in children and adolescents: The 1996 annual report of NAPRTCS. Pediatr Nephrol 1998;12:328-37.

8. Peter WSL, Lambrecht LJ, Macres M. Randomized cross-over study of adverse reactions and cost implications of intravenous push compared with infusion of of iron dextran in hemodialysis patients. Am J Kidney Dis 1996;28:523-8.

9. Kalantar-Zadeh K, Höffken B, Wünsch H, Fink H, Kleiner M, Luft FC. Diagnosis of iron deficiency anemia in renal failure patients during the posterythropoietin era. Am J Kidney Dis 1995;26:292-9.

10. Fernandez-Rodriguez AM, Guindeo-Casasus MC, Morelo-Labarta T, Dominguez-Cabrera C, HortalCascon K, Perez-Borges P, et al. Diagnosis of iron deficiency in chronic renal failure. Am J Kidney Dis 1999;34:508-13.

11. Oski FA. Differential diagnosis of anemia. In: Nathan DG, Oski FA, editors. Hematology of infancy and childhood. 4th ed. Philadelphia: W. B. Saunders Co.; 1993. p. 346-53.

12. Maiz HB, Abderrahim E, Zouaghi K. Anemia and endstage renal disease in developing world. Artif Organs. 2002;26:760-4.

13. Rigden SPA. Chronic renal failure. In: Postlethwaite RJ, editor. Clinical paediatric nephrology. Oxford: Butterworth-Heinemann Ltd; 1994. p. 266-81.

14. De Maeyer EM. Preventing and controlling iron deficiency anemia through primary health care. A guide for health admthisstrators and programme managers. Geneva: WHO; 1989. 


\section{Paediatrica Indonesiana}

15. Dallman PR, Yip R, Oski FA. Iron deficiency and related nutritional anemias. In: Nathan DG, Oski FA, editors. Hematology of infancy and childhood. 4th ed. Philadelphia: Saunders; 1993. p. 413-50.

16. Pudjiadi S. Ilmu gizi klinis pada anak. 4th ed. Jakarta: Balai Penerbit FKUI; 2001. p. 100.

17. Akinsola A, Durosinmi MO, Akinsola NO. The haematological profile of Nigerians with chronic renal failure. Afr J Med Sci 2002;9:13-6.

18. Maandi K, Otoukesh H, Rastegar A, Why SV. Chronic renal failure in Iranian children. Pediatr Nephrol 2001; 16:140-4.
19. Logomarsimo E, Valenzuela A, Cavagnaro F, Solar E. Chronic renal failure in pediatrics 1996: Chilean survey. Pediatr Nephrol 1999;13:288-91.

20. Trihono PP. Penatalaksanaan gagal ginjal kronik pada anak. In: Kumpulan makalah Simposium Nasional Nefrologi VII and PIBIKA VIII FK UNHAS. Ujung Pandang, 26-27 Juni 1998.

21. Talwar VK, Gupta HL, Shashinarayan. Clnicohaematological profile in chronic renal failure. J Assoc Physicians India 2002;50:228-33.

22. Wu AC, Lesperance L, Bernstein H. Screening for iron deficiency. Pediatr Rev 2002;23:171-8. 